\title{
PENGEMBANGAN SISTEM UJIAN ONLINE MINAT DAN BAKAT SISWA SMK PADA SMK ISLAM BATU
}

\author{
Mohammad Dandy Amarta S, KarinaAuliasari, Ahmad Faisol \\ Program Studi Teknik Informatika S1, Fakultas Teknologi Industri \\ Institut Teknologi Nasional Malang, Jalan Raya Karanglo km 2 Malang, Indonesia \\ Dandyamarta211@gmail.com
}

\begin{abstract}
ABSTRAK
Ujian merupakan salah satu cara untuk mengevaluasi proses belajar. Pada umumnya ujian yang diadakan oleh pihak sekolah masih menggunakan kertas dan proses penilaiannya masih menggunakan cara manual, hal tersebut tidak dapat memudahkan para siswa dalam melakukan ujian dan mendapatkan informasi hasil ujian yang cepat karena keterbatasan waktu. Oleh karena itu, penelitian ini bertujuan untuk merancang website ujian online untuk SMK ISLAM KOTA BATU dengan metode Linear Congruental Generator menggunakan XAMPP yang merupakan gabungan dari apache web server, PHP dan MySQL dan browser google crome. Sehingga dapat memudahkan pelaksanaan ujian dibandingkan menggunakan kertas dan pemeriksaan manual, karena dengan adanya aplikasi ujian online dapat membantu dalam pelaksaan ujian di SMK ISLAM KOTA BATU. Aplikasi ujian online minat dan bakat ini dapat membantu khususnya para siswa di SMK ISLAM KOTA BATU untuk memudahkan dalam melaksanakan penerimaan peserta didik baru. Aplikasi ini juga memudahkan para guru untuk mengambil nilai hasil ujian tanpa harus memeriksanya satu per satu terlebih dahulu.
\end{abstract}

Kata Kunci: Website, Ujian Minat dan Bakat, Linear Congruental Generator.

\section{PENDAHULUAN}

Setiap tahun, siswa kelas XII SMK yang berencana melanjutkan program studinya ke jenjang perguruan tinggi selalu bingung dalam menentukan jurusan atau bidang studi yang harus di pilih. Hal ini cukup sulit mengingat referensi yang di miliki siswa SMK tersebut cukup sedikit terkait perguruan tinggi, Seringkali pilihan siswa tidak sesuai dengan bakat dan minat yang sesungguhnya dari siswa, meskipun siswa tersebut terpaksa mendaftar kembali pada tahun berikutnya, karena merasa tidak cocok atau mengalami kesulitan dengan jurusan yang dipilihnya, sehingga berdampak pula pada biaya pendidikan yang sudah di keluarkan oleh orang tua siswa tersebut. Dengan demikian adalah sangat penting bagi siswa untuk memahami potensi yang ada pada dirinya.

Dengan adanya pemahaman diri, siswa diharapkan dapat mengetahui dan memahami kekuatan (kelebihan) dan kelemahan (kekurangan) dirinya sendiri, sehingga siswa dapat mengarahkan diri dan membuat keputusan secara tepat dalam mewujudkan dirinya secara optimal, Sebuah cara yang umumnya di pakai untuk memilih jurusan yang sesuai adalah dengan melihat kecenderungan nilai di setiap mata pelajaran selama di SMK, siswa biasanya akan memilih mata pelajaran yang di sukai dan menghasilkan nilai yang tinggi di rapornya,dan cara kedua adalah dengan melihat hasil test bakat atau psikologi yang di dapat dari test yang di adakan di sekolahnya atau di tempat bimbingan belajar.

Dua solusi yang di tawarkan ini biasanya dilakakukan secara terpisah. Namun, masing masing cara di rasa memiliki kelemahan, beberapa orang tua sering bertanya, seberapa relevan hasil tes psikologi tersebut, terutama saat siswa mengalami kondisi lelah atau mental yang kurang sehat. Akhirnya orang tua harus melakukan pengamatan pada nilai akademisnya, kedua kombinasi ini adalah di rasa yang terbaik pada saat orang tua harus menentukan jurusan yang pas untuk anaknya dalam menentukan jurusan di perguruan tinggi. secara umum hasil studi itu menunjukan bahwa kekompakan bakat dengan minat bisa membuat sang anak mencapai keberhasilan. sebaliknya, jika seseorang memiliki minat namun tidak memiliki bakat, kemungkinan dia akan mendapatkan indeks prestasi yang minim, Berdasarkan latar belakang permasalahan tersebut maka penulis memilih judul: "Pengembangan Sistem Ujian Online Minat dan Bakat Siswa SMK Menggunakan Metode LCG (Linear Congruental Generator Pada Smk Islam Batu)".

\section{TINJAUAN PUSTAKA}

\subsection{Penelitian Terdahulu}

Menurut Jogiyanto (2005:2) menerangkan "sistem adalah sekumpulan dari elemen-elemen yang berinteraksi untuk mencapai satu tujuan tertentu" [1]. Sedangkan menurut Raymond McLeod, Jr (2001:9) menyatakan bahwa "sistem adalah sekelompok elemen-elemen yang terintegrasi dengan maksud yang sama untuk mencapaisuatu tujuan". Dalam proses ujian SMK Muhammadiyah 1 Padang masih mengunakan ujian manual dimana penyajian dan pendistribusian soal dilakukan oleh guru dalam memulai ujian dalam kelas. Dalam hal penyajian soal guru hanya mengetik soal pada kertas dan membagikan soal tersebut satu persatu kepada siswa dan siswa dimintak untuk menjawab kedalam Lembar 
Kerja Siswa (LKS) Analisis yang digunakan untuk menganalisa sistem ujian online ini untuk dapat mengenali penyebab masalah yaitu menggunakan metode PIECES (Performance, Information, Economic, Control, Efficiency, Service). Dengan analisa tersebut, maka dapat diperoleh beberapa penyebab masalah yang jelas dan lebih spesifik pada titik permasalahannya sehingga membantu dalam merancang sistem baru yang lebih baik. Sistem di sekolah yang salah satunya adalah sistem penyelenggaraan ujian sekolah dianalisa dengan menggunakan metode PIECES sebagai dasar untuk memperoleh pokok-pokok permasalahan 'yang lebih jelas dan spesifik [2] . Sistem ujian online atau juga disebut dengan sistem informasi ujian online merupakan sebuah aplikasi sistem ujian atau tes yang dibangun berbasis web sebagai interface-nya. Selain itu, sistem informasi ujian online diharapkan mampu memberikan metode ujian yang efektif dan efesien bagi pihak yang berkepentingan dalam hal ini guru dan siswa [3].

Perancangan aplikasi web ini dibuat agar mengurangi penggunaan media kertas dan alat tulis sebagai penunjang kegiatan ujian. Kemudian dalam pembuatan web ini dirancang menggunakan struktur navigasi, use case diagram, activity diagram, dan class diagram. Sedangkan pada tahapan ketiga yaitu pembuatan aplikasi web, pada tahap ini mulai dilakukan penerapan dan membangun rancangan yang telah dibuat pada tahapan perancangan aplikasi web dengan membuat coding program [1]. Tahap terakhir yaitu implementasi, pada tahap ini dilakukan implementasi dimana dilakukannya ujicoba terhadap aplikasi yang telah dibuat Metode Linear Congruential Generator (LCG) adalah salah satu algoritma pseudo random number yang tertua dan paling populer. Teori dari algoritma ini mudah dipahami dan dapatdiimplementasikan secara cepat. Selain itu Linear Congruential Generator dapat diterapkan pada aplikasi simulasi lain karena algoritma ini sangat e sien secara waktu proses dan hemat penggunaan memori [2]. LCG dapat diterapkan untuk menghasilkan sekumpulan nilai acak ataupun dapat digunakan untuk mengacak posisi dari sekumpulan nilai. Berdasarkan uraian tersebut maka penerapan Metode Linear Congruential Generator digunakan untuk mengacak soal-soal ujian agar tidak terjadi kesamaan soal antara satu siswa dengan siswa lainnya Aplikasi ujian online berbasis website ini dibuat untuk mengurangi penggunaan kertas dalam setiap ujian dan mempercepat dalam pengolahan hasil ujian. Berdasarkan hasil pengujian dan pembahasan yang telah dilakukan aplikasi ujian online berbasis website [3].

Ujian merupakan tes evaluasi hasil belajar untuk mengetahui kemampuan siswa memahami pengetahuan yang dikuasai selama sesi pembeajaran tertentu. Proses ujian merupakan proses yang digunakan untuk mengukur penguasaan pelajar dalam sesuatu kegiatan belajar mengajar [1]. Sistem pada ujian saat ini terdapat dua macam, sistem ujian yang menggunakan kertas dan alat tulis disebut dengan ujian konvensional, sedangkan sistem ujian yang menggunakan komputer, smartphone dan juga akses internet disebut dengan ujian online [2]. Untuk mengurangi penggunaan kertas pada hal ujian, maka sistem yang digunakan pada ujian kini menggunakan sistem komputerisasi atau disebut juga ujian online yang dapat memudahkan proses ujian dan juga dapat menghemat penggunaan kertas. Di saat ujian sedang dilaksanakan harus diperhatikan juga adanya beberapa tindak kecurangan yang dapat dilakukan siswa. Kecurangan dalam pelaksanaan Ujian banyak terjadi di setiap sekolah yang ada di Indonesia [3]. Curang merupakan perbuatan yang menggunakan cara yang tidak sah untuk mendapatkan keberhasilan akademis atau menghindari kegagalan akademis. Salah satunya adalah seorang siswa memberikan jawabannya kepada siswa yang lain, lalu siswa tersebut menyalin jawaban yang telah diberikan [4]. Pada SMAN 1 Sukaraja sistem ujian yang digunakan saat ini masih menggunakan sistem ujian menggunakan kertas dan alat tulis atau bisa disebut juga dengan ujian konvensional. Dimana setiap siswa diharuskan mengikuti ujian tersebut yang diberikan oleh guru dengan selembaran kertas soal dan jawaban. Setiap siswa yang mengikuti ujian tersebut tidak terlepas dari tindak kecurangan, dimana siswa tersebut mencontek soal jawaban, dikarenakan adanya soal yang sama. Dengan di gunakannya sistem tersebut maka pemakaian media kertas akan terus menerus bertambah dan tindak kecurangan akan selalu terjadi, untuk itu perlu adanya tindakan yang dapat diterapkan untuk meminimalisir dan mengantisipasi hal tersebut. Algoritma LCG (Linier Congruential Generator) adalah sebuah metode yang berfungsi untuk membangkitkan bilangan acak yang banyak dipergunakan dalam program komputer.

\subsection{Dasar Teori}

\subsubsection{Ujian Bidang Minat dan Bakat Bagi Peserta Didik Smk.}

Algoritma LCG (Linear Congruential Generator) merupakan pembangkit dari sebuah bilangan yang dapat dilakukan dalam berbagai cara. Sebuah bilangan acak didapat dengan beberapa cara, seperti dalam pelemparan dadu, pembacaan tabel bilangan acak, dan lainnya. Pada sekitar tahun 1940 hingga sekarang, sebuah bilangan acak dibangkitkan secara numerik dan aritmatik yang digunakan komputer. Bilangan acak yang berasal dari pembangkitan bilangan acak dengan metode tersebut dengan bilangan acak semu.

Linear Congruential Generator (LCG) merupakan pembangkit bilangan acak sederhana, mudah di mengerti teorinya, dan mudah untuk di implementasikan. LCG didefinisikan dalam relasi berulang berikut:

$\mathrm{Xn}=(\mathrm{aXn}-1+\mathrm{b}) \bmod \mathrm{m}$

Keterangan: 
$\mathrm{Xn}=$ bilangan acak ke-n dari deretnya

$\mathrm{Xn}-1$ = bilangan acak sebelumnya

$a=$ faktor pengali

$\mathrm{b}=$ increment $\mathrm{m}=$ modulus

LCG memiliki periode penuh jika:

1 . b relatif prima terhadap $m$.

2. a -1 dapat dibagi dengan setiap faktor prima dari $\mathrm{m}$.

3. a - 1 adalah kelipatan 4 jika m kelipatan

$\mathrm{X} 0$ adalah kunci pembangkit atau disebut juga umpan (seed). LCG mempunyai periode tidak lebih besar dari $\mathrm{m}$, dan pada kebanyakan kasus periodenya kurang dari itu.

\subsection{2 ХАМPP}

XAMP dari Apache, Mysql, PHP dan Perl adalah perangkat lunak bebas, yang mendukung banyak sistem operasi, merupakan kompilasi dari beberapa program. $X A M P P$ memiliki arti sebagai berikut:

a. $X$ : Program ini dapat dijalankan dibanyak sistem operasi seperti Windows, Linux, dan Mac $O S$.

b. A : Apache merupakan aplikasi web server. Tugas utama Apache adalah menghasilkan halaman web kepada user berdasarkan kode PHP yang dituliskan oleh pembuat web.

c. $M:$ Mysql merupakan aplikasi database server, bahasa terstruktur yang digunakan untuk membuat dan mengelola database beserta isinya pengguna dapat memanfaatkan Mysql untuk menambahkan, mengubah, dan menghapus data yang berada dalam database.

d. $P: P H P$ merupakan bahasa pemrograman web yang bersifat server-side scripting.

e. $P$ : Perl merupakan bahasa pemrograman untuk segala keperluan, dikembangkan, pertama kali oleh Larry Wall di mesin Unix.

\subsubsection{JavaScript}

Menurut (Wahana Komputer, 2010:1) JavaScript merupakan bahasa pemrograman yang berbentuk kumpulan skrip yang memiliki fungsi untuk memberikan tampilan agar tampak lebih interaktif pada dokumen web. Pengertian di atas dapat disimpulkan bahwa Javascript adalah bahasa pemrograman untuk memberikan kemampuan tambahan ke dalam bahasa pemrograman HTML atau juga digunakan untuk menjelaskan tampilan dalam halaman website.

\subsubsection{CodeIgniter}

CodeIgniter adalah sebuah web application network yang bersifat open source yang digunakan untuk membangun sebuah aplikasi php dinamis.CodeIgniter menjadi sebuah framework PHP dengan model MVC untuk membangun sebuah website dinamis dengan menggunakan PHP yang dapat mempercepat pengembang untuk membuat sebuah aplikasi web. Selain ringan dan cepat,
CodeIgniter juga memiliki dokumentasi yang super lengkap disertai dengan contoh implementasi kodenya. Dokumentasi yang lengkap inilah yang menjadi salah satu alasan kuat mengapa banyak orang memilih CodeIgniter sebagai framework pilihannya. Karena kelebihan-kelebihan yang dimiliki oleh CodeIgniter, pembuat PHP Rasmus Lerdorf memuji CodeIgniter di frOSCon (Agustus 2008) dengan mengatakan bahwa dia menyukai CodeIgniter karena "it is faster, lighter and the least like a framework."

CodeIgniter pertamakali dikembangkan pada tahun 2006 oleh Rick Ellis. Dengan logo api yang menyala, CodeIgniter dengan cepat "membakar" semangat para web developer untuk mengembangkan web dinamis dengan cepat dan mudah menggunakan framework PHP yang satu ini.

\subsubsection{Database Mysql}

MySql merupakan salah satu software atau aplikasi yang tergolong kedalam database server yang bersifat Open-Source. MySQL atau MariaDB merupakan aplikasi database server yang berperan sebagai mengolah, mengedit, dan menghapus daftar melalui database.

\section{METODE PENELITIAN}

\subsection{Flowchart Sistem Admin}

Flowchart system Admin ini menjelaskan proses berjalananya aplikasi pada sistem admin seperti ditunjukkan pada Gambar 1

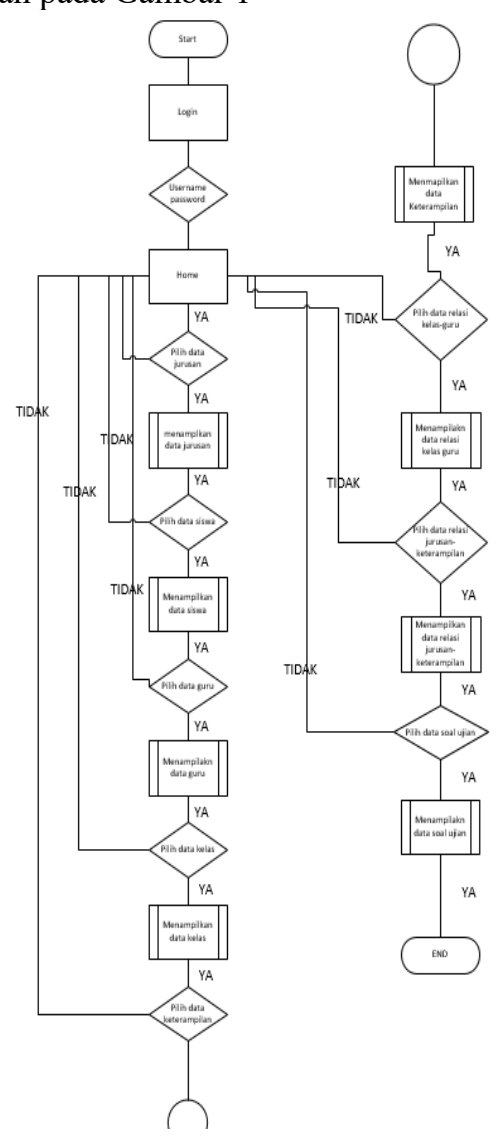

Gambar 1. Flowchart Sistem Admin 
Berdasarkan flowchart pada Gambar 3.1 sistem dimulai dengan Melakukan login terlebih dahulu dan selanjutnya pada halaman dashboard kita dapat memilih menu yang ada pada aplikasi sistem ujian online minat dan bakat untuk mengisi data dari ujian minta dan bakat.

\subsection{Flowchart Sistem Guru}

Flowchart system Admin ini menjelaskan proses berjalananya aplikasi pada Sistem Guru seperti ditunjukkan pada Gambar 2

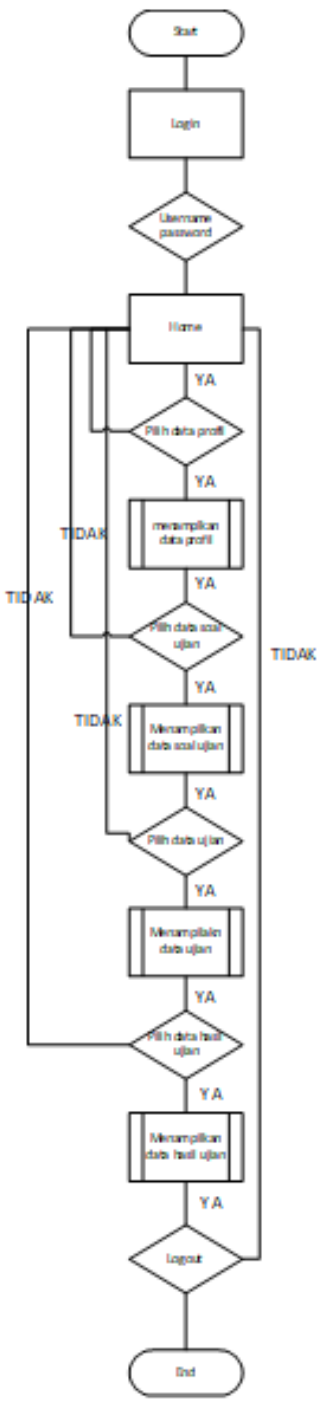

Gambar 2. Flowchart Sistem Guru

Berdasarkan flowchart pada Gambar 3.2 sistem Guru dimulai dengan Melakukan login terlebih dahulu dan selanjutnya pada menu Soal ujian Guru dapat membuat soal untuk di kerjakan oleh calon siswa yang akan melaksanakan ujian dan guru dapat melihat hasil akhir ujian yang telah di dapat oleh siswa yang telah melaksanakan ujian minat dan bakat

\subsection{Flowchart Sistem Siswa}

Flowchart system Siswa ini menjelaskan proses berjalananya aplikasi seperti ditunjukkan pada Sistem Siswa Gambar 3

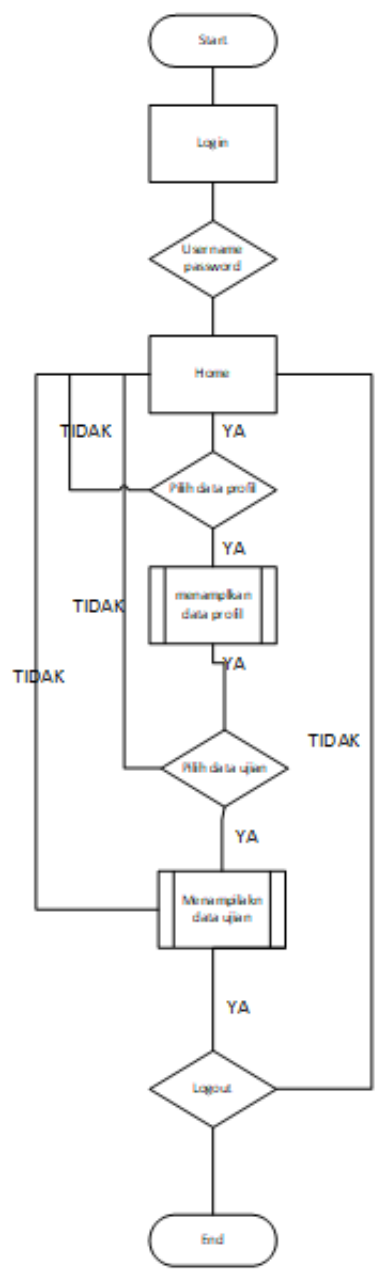

Gambar 3. Flowchart Sistem Siswa

Berdasarkan flowchart pada Gambar 3, sistem dimulai dengan melakukan login terlebih dahulu jika selesai login siswa dapat melakukan ujian sesuai waktu yang telah di temtukan jika waktu ujian di mulai maka siswa akan terlebih dahulu memasukkan token ujian untuk memulai ujian minat dan bakat.

\section{HASIL DAN PEMBAHASAN \\ 4.1. Hasil Sistem Halaman Login}

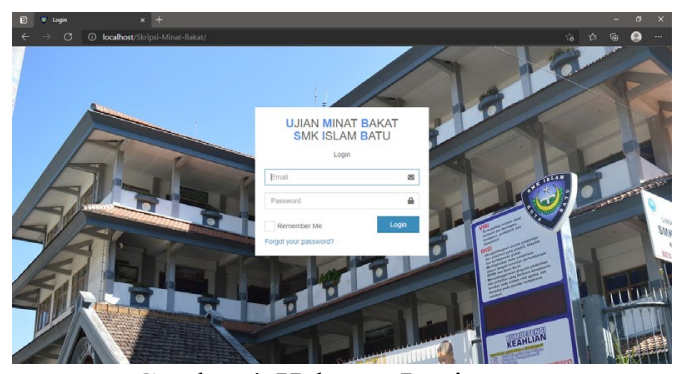

Gambar 4. Halaman Login 
Gambar 4 Pada Halaman Login Admin,Guru,Siswa harus login menggunkan email dan Nis Atau Nip untuk Guru untuk login ke halaman masing-masing yang telah di tentukan.

\subsection{Hasil Sistem Halaman Admin}

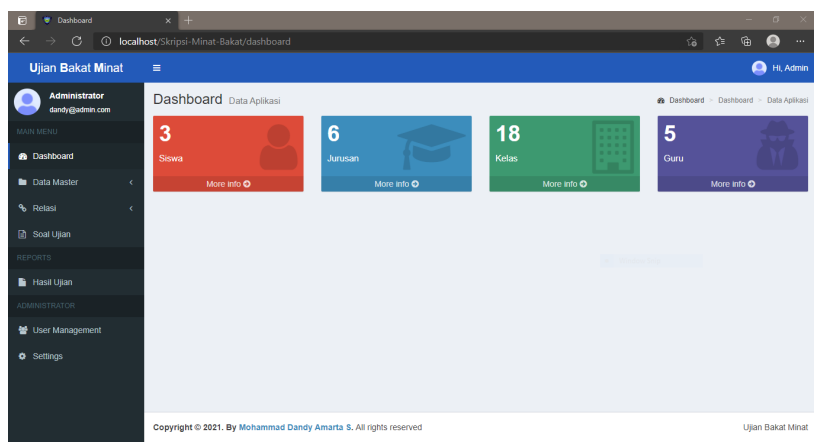

Gambar 5. Halaman Dashboard Admin

Gambar 5 merupakan Tampilan halaman dashboard admin di mana pada tampilan halaman admin menyediakan menu data Master, Relasi, Soal Ujian, dan Hasil Ujian.

\subsection{Hasil Sistem Halaman Guru}

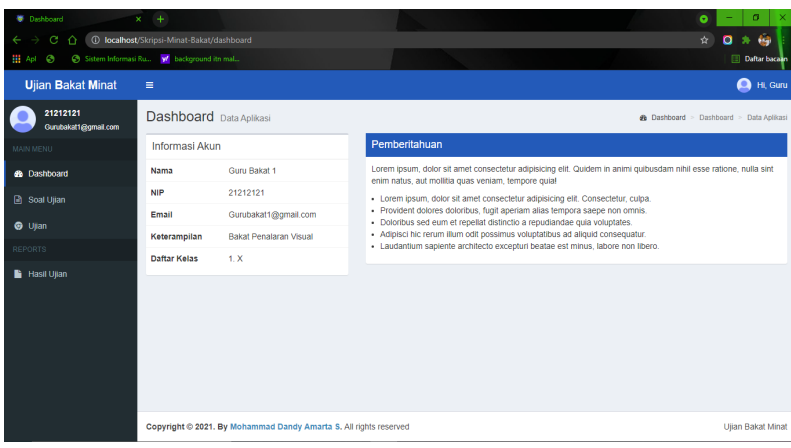

Gambar 6. Halaman Guru

Gambar 6 Merupakan Halaman Guru Dimana pada halaman guru bisa membuat ujian untuk ujian minat dan bakat bagi calon siswa yang mau menjalani ujian minat dan bakat.

\subsection{Hasil Sistem Halaman Buat Soal}

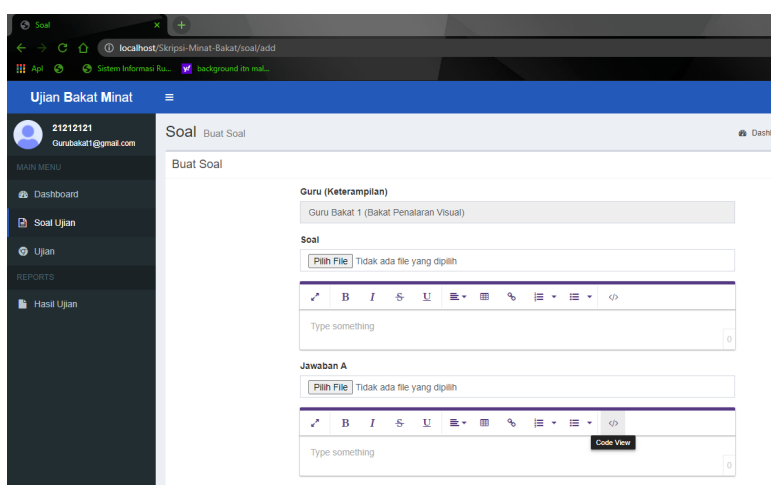

Gambar 7. Halaman Buat Soal
Gambar 7 Merupakan Halaman Membuat Soal dimana pada halaman membuat soal pada sistem halam guru untuk mempersiapkan soal ujian bagi calon siswa baru yang mau melaksanakan ujian.

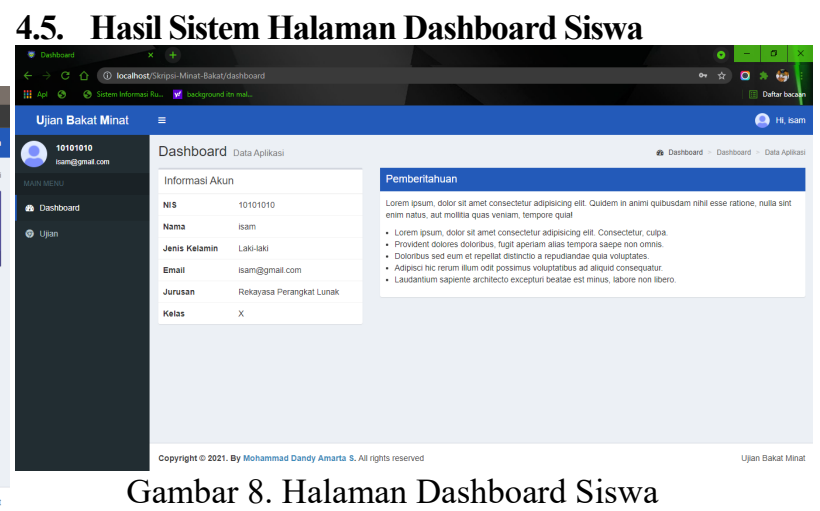

Gambar 8 Merupakan Halaman Dashboard Siswa dimana Pada halaman dashboard siswa menyediakan tampilan Untuk Ujian Siswa.

\subsection{Hasil Sistem Halaman Menunggu Ujian}

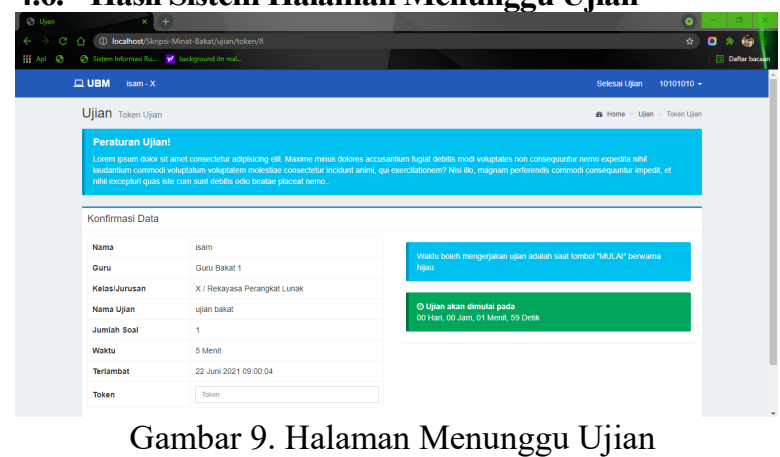

Gambar 9 Merupakan Halaman Untuk Menunggu dimulainya ujian bagi calon siswa yang mau melaksanakan ujian dan sebelum melaksanakan ujian calon siswa di harapkan memasukkan token ujian untuk bisa memulai ujian.

\subsection{Hasil Sistem Halaman Pengerjaan Soal Ujian}

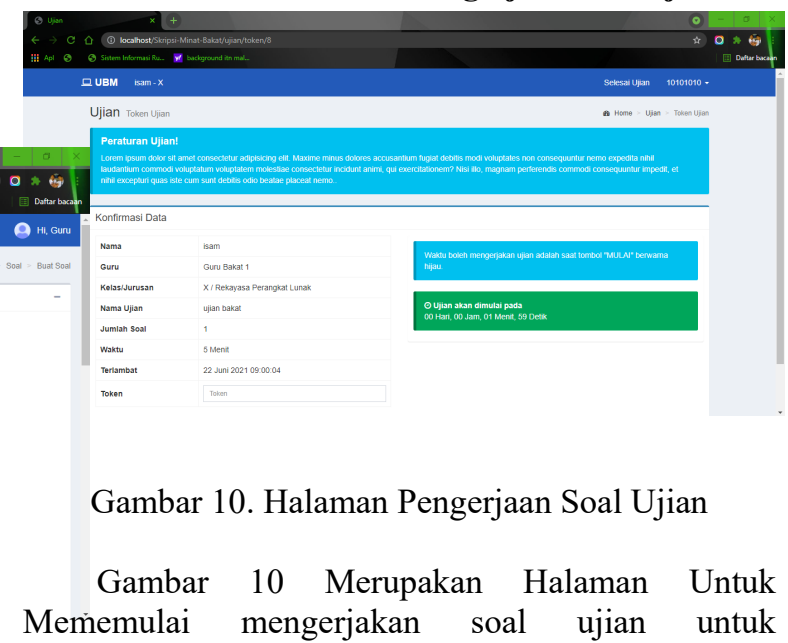


mengetahui hasil akhir dari pengerjaan soal ujian minat dan bakat.

\subsection{Pengujian Hasil Ujian Minat dan Bakat}

1. User Siswa Pertama

Mengetahui Hasil Ujian Minat Dan Bakat Yang

Telah Diperoleh

Nama : M.Fajri Zulianto

\begin{tabular}{|c|c|}
\hline Ujian & Nilai \\
\hline Minat & 80 \\
\hline Bakat & 80 \\
\hline
\end{tabular}

2. User Siswa Kedua

Mengetahui Hasil Ujian Minat Dan Bakat Yang

Telah Diperoleh

Nama : Fatkhur Rozi

\begin{tabular}{|c|c|}
\hline Ujian & Nilai \\
\hline Minat & 80 \\
\hline Bakat & 70 \\
\hline
\end{tabular}

3. User Siswa Ketiga

Mengetahui Hasil Ujian Minat Dan Bakat Yang

Telah Diperoleh

Nama : Roy Bravi Zulfan

\begin{tabular}{|c|c|}
\hline Ujian & Nilai \\
\hline Minat & 70 \\
\hline Bakat & 90 \\
\hline
\end{tabular}

4. User Siswa Keempat

Mengetahui Hasil Ujian Minat Dan Bakat Yang

Telah Diperoleh

Nama : M.Misbachul Sifak

\begin{tabular}{|c|c|}
\hline Ujian & Nilai \\
\hline Minat & 80 \\
\hline Bakat & 90 \\
\hline
\end{tabular}

5. User Siswa Kelima

Mengetahui Hasil Ujian Minat Dan Bakat Yang

Telah Diperoleh

Nama : Asy Sam Fathir A.N

\begin{tabular}{|c|c|}
\hline Ujian & Nilai \\
\hline Minat & 60 \\
\hline Bakat & 90 \\
\hline
\end{tabular}

6. User Siswa Keenam

Mengetahui Hasil Ujian Minat Dan Bakat Yang

Telah Diperoleh

Nama : Erlangga Arif Putra Bakti

\begin{tabular}{|c|c|}
\hline Ujian & Nilai \\
\hline Minat & 60 \\
\hline Bakat & 80 \\
\hline
\end{tabular}

\subsection{Pengujian Fungsional}

Pengujian Fungsional Menggunakan Metode Black-Box :
Tabel 1. Pengujian Metode Black-Box

\begin{tabular}{|c|c|c|c|c|}
\hline No & $\begin{array}{c}\text { Fitur/ } \\
\text { Fungsi- } \\
\text { uyonal }\end{array}$ & Kasus Uji & $\begin{array}{l}\text { Hasil Yang } \\
\text { Diharapkan }\end{array}$ & $\begin{array}{c}\text { Hasil } \\
\text { Pengujian }\end{array}$ \\
\hline 1 & Login & $\begin{array}{l}\text { Penggunaan } \\
\text { menekan } \\
\text { tombol login } \\
\text { sebelum } \\
\text { memasukkan } \\
\text { Email dan } \\
\text { password(Email } \\
\text { dan Password } \\
\text { Kosong) } \\
\end{array}$ & $\begin{array}{l}\text { Aplikasi } \\
\text { Menampilkan } \\
\text { pesan kesalahan } \\
\text { bahwa email dan } \\
\text { password harus diisi }\end{array}$ & $\begin{array}{l}\text { Valid/Sesuai } \\
\text { (Bukti } \\
\text { screenshot di } \\
\text { lampiran) }\end{array}$ \\
\hline 2 & Login & $\begin{array}{l}\text { Pengguna login } \\
\text { dengan } \\
\text { menggunakan } \\
\text { email dan } \\
\text { password yang } \\
\text { tidak terdaftar di } \\
\text { database / Email } \\
\text { dan password } \\
\text { salah }\end{array}$ & $\begin{array}{l}\text { Aplikasi } \\
\text { menampilkan } \\
\text { pesan kesalahan } \\
\text { karena } \\
\text { email dan password } \\
\text { tidak ada dalam } \\
\text { database atau email } \\
\text { dan password salah }\end{array}$ & $\begin{array}{l}\text { Valid/Sesuai } \\
\text { (Bukti } \\
\text { screenshot di } \\
\text { lampiran) }\end{array}$ \\
\hline 3 & $\begin{array}{l}\text { Kelola } \\
\text { Data } \\
\text { Jurusan }\end{array}$ & $\begin{array}{l}\text { Jika pengguna } \\
\text { menekan tombol } \\
\text { kelola data jurusan } \\
\text { yang belum di isi } \\
\text { atau data kosong. }\end{array}$ & $\begin{array}{l}\text { Aplikasi } \\
\text { Menampilkan } \\
\text { Pesan kesalahan atau } \\
\text { kolom kelola data } \\
\text { Jurusan wajib diisi } \\
\text { tidak boleh kosong. }\end{array}$ & $\begin{array}{l}\text { Valid/Sesuai } \\
\text { (Bukti } \\
\text { screenshot di } \\
\text { lampiran) }\end{array}$ \\
\hline 4 & $\begin{array}{l}\text { Kelola } \\
\text { Data } \\
\text { Kelas }\end{array}$ & $\begin{array}{l}\text { Jika pengguna } \\
\text { menekan tombol } \\
\text { kelola data Kelas } \\
\text { yang belum di isi } \\
\text { atau data kosong. }\end{array}$ & $\begin{array}{l}\text { Aplikasi } \\
\text { Menampilkan } \\
\text { Pesan kesalahan atau } \\
\text { kolom kelola data } \\
\text { Kelas } \\
\text { wajib diisi/tidak } \\
\text { boleh kosong. } \\
\end{array}$ & $\begin{array}{l}\text { Valid/Sesuai } \\
\text { (Bukti } \\
\text { screenshot di } \\
\text { lampiran) }\end{array}$ \\
\hline 5 & $\begin{array}{l}\text { Kelola } \\
\text { Data } \\
\text { Keteram } \\
\text { pilan }\end{array}$ & $\begin{array}{l}\text { Jika pengguna } \\
\text { menekan tombol } \\
\text { kelola data } \\
\text { Keterampilan yang } \\
\text { belum di isi atau } \\
\text { data kosong. }\end{array}$ & $\begin{array}{l}\text { Aplikasi } \\
\text { Menampilkan Pesan } \\
\text { kesalahan atau } \\
\text { kolom kelola } \\
\text { data Keterampilan } \\
\text { wajib diisi/tidak } \\
\text { boleh kosong. }\end{array}$ & $\begin{array}{l}\text { Valid/Sesuai } \\
\text { (Bukti } \\
\text { screenshot } \\
\text { di lampiran) }\end{array}$ \\
\hline 6 & $\begin{array}{l}\text { Kelola } \\
\text { Data } \\
\text { Guru }\end{array}$ & $\begin{array}{l}\text { Jika pengguna } \\
\text { menekan tombol } \\
\text { kelola data Guru } \\
\text { yang belum di isi } \\
\text { atau data kosong. }\end{array}$ & $\begin{array}{l}\text { Aplikasi } \\
\text { Menampilkan } \\
\text { Pesan kesalahan } \\
\text { atau kolom kelola } \\
\text { data Guru wajib } \\
\text { diisi/tidak boleh } \\
\text { kosong. } \\
\end{array}$ & $\begin{array}{l}\text { Valid/Sesuai } \\
\text { (Bukti } \\
\text { screenshot } \\
\text { di lampiran) }\end{array}$ \\
\hline 7 & $\begin{array}{l}\text { Kelola } \\
\text { Data } \\
\text { Siswa }\end{array}$ & $\begin{array}{l}\text { Jika pengguna } \\
\text { menekan tombol } \\
\text { kelola data Siswa } \\
\text { yang belum di isi } \\
\text { atau data kosong. }\end{array}$ & $\begin{array}{l}\text { Aplikasi } \\
\text { Menampilkan } \\
\text { Pesan } \\
\text { kesalahan } \\
\text { atau kolom } \\
\text { kelola } \\
\text { data Siswa wajib } \\
\text { diisi/tidak } \\
\text { boleh kosong. }\end{array}$ & $\begin{array}{l}\text { Valid/Sesuai } \\
\text { (Bukti } \\
\text { screenshot } \\
\text { di lampiran) }\end{array}$ \\
\hline 8 & $\begin{array}{l}\text { Relasi } \\
\text { Kela } \\
\text { s-Guru }\end{array}$ & $\begin{array}{l}\text { Jika pengguna } \\
\text { menekan tombol } \\
\text { kelola data Relasi } \\
\text { Kelas-Guru yang } \\
\text { belum di isi atau } \\
\text { data kosong. }\end{array}$ & $\begin{array}{l}\text { Aplikasi } \\
\text { Menampilkan } \\
\text { Pesan } \\
\text { kesalahan } \\
\text { atau kolom } \\
\text { kelola } \\
\text { data Relasi } \\
\text { Kelas-Guru } \\
\text { wajib } \\
\text { diisi/tidak } \\
\text { boleh kosong. }\end{array}$ & $\begin{array}{l}\text { Valid/Sesuai } \\
\text { (Bukti } \\
\text { screenshot } \\
\text { di lampiran) }\end{array}$ \\
\hline 9 & $\begin{array}{l}\text { Relasi } \\
\text { Jurusan- } \\
\text { Keteram } \\
\text { pilan }\end{array}$ & $\begin{array}{l}\text { Jika pengguna } \\
\text { menekan tombol } \\
\text { kelola data Relasi } \\
\text { Jurusan- } \\
\text { Keterampilan yang } \\
\text { belum di isi atau } \\
\text { data kosong. }\end{array}$ & $\begin{array}{l}\text { Aplikasi } \\
\text { Menampilkan Pesan } \\
\text { kesalahan atau } \\
\text { kolom } \\
\text { kelola data Relasi } \\
\text { Jurusan-Keterampilan } \\
\text { wajib diisi/tidak } \\
\text { boleh kosong. } \\
\end{array}$ & $\begin{array}{l}\text { Valid/Sesuai } \\
\text { (Bukti } \\
\text { screenshot di } \\
\text { lampiran) }\end{array}$ \\
\hline 10 & $\begin{array}{l}\text { Soal } \\
\text { Ujian }\end{array}$ & $\begin{array}{l}\text { Jika pengguna } \\
\text { menekan tombol } \\
\text { kelola data Soal } \\
\text { Ujian yang belum } \\
\text { di isi atau data } \\
\text { kosong. }\end{array}$ & $\begin{array}{l}\text { Aplikasi } \\
\text { Menampilkan } \\
\text { Pesan kesalahan atau } \\
\text { kolom kelola data } \\
\text { Soal Ujian wajib } \\
\text { diisi/tidak boleh } \\
\text { kosong. }\end{array}$ & $\begin{array}{l}\text { Valid/Sesuai } \\
\text { (Bukti } \\
\text { screenshot di } \\
\text { lampiran) }\end{array}$ \\
\hline 11 & Ujian & $\begin{array}{l}\text { Jika Pengguna } \\
\text { tidak memilih } \\
\text { jawab dan } \\
\text { menekan tombol } \\
\text { teruskan }\end{array}$ & $\begin{array}{l}\text { Aplikasi } \\
\text { menampilkan pesan } \\
\text { soal ujian wajib } \\
\text { di jawab atau di isi }\end{array}$ & $\begin{array}{l}\text { Valid/Sesuai } \\
\text { (Bukti } \\
\text { screenshot } \\
\text { di lampiran) }\end{array}$ \\
\hline
\end{tabular}

Penjelasan Tabel 1:

Bahwa Dari Semua Hasil Pengujian yang sudah di lakukan dengan sukses dan dapat di jalankan dengan lancar tanpa ada gangguan atau eror dalam program 
maka fitur dalam website bisa di jalankan dan digunakan.

\subsection{Pengujian Kepuasan User}

Berdasarkan tujuan dibuatnya Website Ujian Online Minat Dan Bakat untuk menentukan Jurusan Sekolah, user yang bernama M. Fajri Zulianto yaitu siswa kelas 3 SMPN 06 Batu telah menjalankan dan Mencoba Ujian Di Sistem Ujian Minat Dan Bakat. Berikut tabel kepuasan user.

Tabel 2. uji kepuasan user pertama.

\begin{tabular}{|l|l|l|}
\hline No. & \multicolumn{1}{|c|}{ Aspek Kepuasan } & \multicolumn{1}{|c|}{ Hasil Uji } \\
\hline 1. & Tampilan & Puas \\
\hline 2. & Kemudahan penggunaan & Sangat Puas \\
\hline 3. & Kelengkapan fitur & Puas \\
\hline 4. & Manfaat & Puas \\
\hline 5. & Informasi yang diperoleh & Sangat Puas \\
\hline
\end{tabular}

Tabel 3. uji kepuasan user kedua.

\begin{tabular}{|l|l|l|}
\hline No. & \multicolumn{1}{|c|}{ Aspek Kepuasan } & \multicolumn{1}{c|}{ Hasil Uji } \\
\hline 1. & Tampilan & Sangat Puas \\
\hline 2. & Kemudahan penggunaan & Sangat Puas \\
\hline 3. & Kelengkapan fitur & Puas \\
\hline 4. & Manfaat & Sangat Puas \\
\hline 5. & Informasi yang diperoleh & Sangat Puas \\
\hline
\end{tabular}

Tabel 4. uji kepuasan user ketiga.

\begin{tabular}{|l|l|l|}
\hline No. & \multicolumn{1}{|c|}{ Aspek Kepuasan } & \multicolumn{1}{|c|}{ Hasil Uji } \\
\hline 1. & Tampilan & Puas \\
\hline 2. & Kemudahan penggunaan & Sangat Puas \\
\hline 3. & Kelengkapan fitur & Puas \\
\hline 4. & Manfaat & Puas \\
\hline 5. & Informasi yang diperoleh & Sangat Puas \\
\hline
\end{tabular}

Tabel 5. uji kepuasan user keempat.

\begin{tabular}{|l|l|l|}
\hline No. & \multicolumn{1}{|c|}{ Aspek Kepuasan } & \multicolumn{1}{c|}{ Hasil Uji } \\
\hline 1. & Tampilan & Puas \\
\hline 2. & Kemudahan penggunaan & Sangat Puas \\
\hline 3. & Kelengkapan fitur & Sangat Puas \\
\hline 4. & Manfaat & Sangat Puas \\
\hline 5. & Informasi yang diperoleh & Sangat Puas \\
\hline
\end{tabular}

Tabel 6. uji kepuasan user kelima.

\begin{tabular}{|l|l|l|}
\hline No. & \multicolumn{1}{|c|}{ Aspek Kepuasan } & \multicolumn{1}{c|}{ Hasil Uji } \\
\hline 1. & Tampilan & Sangat Puas \\
\hline 2. & Kemudahan penggunaan & Sangat Puas \\
\hline 3. & Kelengkapan fitur & Puas \\
\hline 4. & Manfaat & Sangat Puas \\
\hline 5. & Informasi yang diperoleh & Sangat Puas \\
\hline
\end{tabular}

Tabel 7. uji kepuasan user keenam.

\begin{tabular}{|l|l|l|}
\hline No. & \multicolumn{1}{|c|}{ Aspek Kepuasan } & \multicolumn{1}{c|}{ Hasil Uji } \\
\hline 1. & Tampilan & Puas \\
\hline 2. & Kemudahan penggunaan & Sangat Puas \\
\hline 3. & Kelengkapan fitur & Puas \\
\hline 4. & Manfaat & Sangat Puas \\
\hline 5. & Informasi yang diperoleh & Sangat Puas \\
\hline
\end{tabular}

Tampilan meliputi Halaman Admin, Halaman Guru, Halaman Siswa, Halaman Ujian. Menurut user aplikasi mudah dipahami untuk penggunaannya dengan sekali contoh penggunaan dari peneliti. Fitur yang telah dicoba user meliputi SignIn, Ujian Minat,
Ujian Bakat, Hasil Ujian, Update nama user dan Logout. Dengan adanya system ujian minat dan bakat ini user dapat melakukan ujian disekolah SMK ISLAM KOTA BATU dan dapat Menggetahui dimana jurusan yang cocok untuk di masuki di sekolah SMK ISLAM KOTA BATU.

\section{KESIMPULAN DAN SARAN \\ 5.1. Kesimpulan}

Adapun Kesimpulan yang dapat penulis sampaikan setelah pembuatan Website Ujian Minat Dan Bakat Ynag Menggunakan Metode LCG Antara lain yaitu:

1. Pada pengujian fungsionalitas, seluruh fitur aplikasi dapat berjalan baik.

2. Pada pengujian Sistem Ujian Online mampu berlajan dengan baik pada perangkat Laptop.

3. Aplikasi ini dapat menggetahui data jurusan yang pantas untuk di ambil pada smk islam batu

\subsection{Saran}

Saran pengembangan untuk Sistem Ujian Online Minat dan Bakat untuk menentukan gaya Ujian Online yaitu:

1. Diharapkan aplikasi ini dapat dikembangkan dan dapat di gunakan dengan baik.

2. Diharapkan aplikasi dapat login melalui akun google yang telah terdaftar.

3. Diaharapkan aplikasi dapat dikembangkan pada seluruh sekolah lainnya.

\section{DAFTAR PUSTAKA}

[1] Jurnal Ilmiah KOMPUTASI, Volume 16 No :2, September 2017, p-ISSN 1412-9434/e-ISSN 2549-7227.

[2] Fatta, Al Hanif.2007. Analisis dan Perancangan Sistem Informasi.

[3] Sudarto F, Hidayati H, Rafika AS. Peningkatan Mutu Ujian Dari Paper Based Menuju Computer Based. CCIT J. 2012; 5(3): 302-11.

[4] Kadir, A. (2008). tuntunan praktis belajar database menggunakan MySQL ANDI Yogyakarta.

[5] Kusumadewi,Sri dkk 2006 Fuzzy MultiAttribute Decision Making (Fuzzy MADM).

[6] Prasojo Diat Lantip, Riyanto, Teknologi Informasi Pendidikan Gava Media, 2011 Yogyakarta

[7] Pristianto, T 2011 Sistem Pendukung Keputusan Memilih Perguruan Tinggi Swasta Jurusan Komputer Menggunakan Metode Analytical Hierarchy Process(AHP) Fakultas Teknologi Industri Jurusan Teknik Informatika. Univeritas Pembangunan Nasional

[8] Sutarman 2009 Pengantar Teknologi Informasi: Bumi Aksara Moekijati "Sistem Infomasi", Prasojo 2011 Yogyakarta 